Vol 11, Issue 9, 2018

\title{
EVALUATION OF THE CYTOCHROME P450 INHIBITORY EFFECT OF THYME OLEORESIN FROM THYMUS VULGARIS L. - AN IN VITRO STUDY
}

\author{
ROY ANITHA*,ADELINE PERSIA R, THANGAVELU LAKSHMI
}

Department of Pharmacology, Saveetha Dental College, Saveetha Institute of Medical and Technical Sciences, Saveetha University, Chennai, Tamil Nadu, India. Email: anitharoy2015@gmail.com

Received: 18 April 2018, Revised and Accepted: 17 May 2018

\section{ABSTRACT}

Objective: The objective of this study was to evaluate the effect of thyme oleoresin on cytochrome P450 (CYP3A4) enzyme.

Materials and Methods: The different concentrations of thyme oleoresin (5-100 $\mu \mathrm{g} / \mathrm{ml})$ were examined for its inhibitory property toward cytochrome P450 isoform (CYP3A4). Thyme oleoresin, potassium phosphate buffer, CYP450 reagent, and substrate 7-Benzyloxy-4-trifluoromethylcoumarin were added to a 96-well plate. The mixtures were preincubated for $20 \mathrm{~min}$ at room temperature. The fluorescent intensities of the products were measured by PerkinElmer Enspire fluorescence reader using an excitation and emission wavelength of $405 \mathrm{~nm}$ and $460 \mathrm{~nm}$, respectively. Values were expressed as mean \pm standard error mean $(n=3)$. $\mathrm{IC}_{50}$ was calculated by plotting concentrations of thyme against the corresponding percent inhibition.

Results: All the tested concentrations of thyme showed inhibitory effect against CYP3A4 in a dose-dependent manner. At $5 \mu \mathrm{g} / \mathrm{ml}$, it showed a percentage inhibition of $1.82 \pm 0.61$, whereas $100 \mu \mathrm{g} / \mathrm{ml}$ showed $66.05 \pm 0.16$. The $\mathrm{IC}_{50}$ value of thyme for CYP3A4 inhibitory activity was found to be $39.14 \mu \mathrm{g} / \mathrm{ml}$.

Conclusion: This study prove the inhibitory effect of thyme oleoresin on cytochrome P450. The inhibitory effect of thyme oleoresin indicates the possibilities of herb-drug interaction if this extract is co-administered with prescribed drugs that are metabolized by CYP3A4.

Keywords: Thyme oleoresin, Cytochrome P450, Inhibitory assay, Thymus vulgaris.

(C) 2018 The Authors. Published by Innovare Academic Sciences Pvt Ltd. This is an open access article under the CC BY license (http://creativecommons. org/licenses/by/4. 0/) DOI: http://dx.doi.org/10.22159/ajpcr.2018.v11i9.26759

\section{INTRODUCTION}

Plants are extensively explored to evaluate their antibacterial activity, antioxidant activity as well as their effect in various metabolic diseases and cancer. [1-4]. Oleoresins are composed of resins and essential oils obtained from herbs [5,6] and are rich in antioxidants [7-9]. They are extensively used in pharmaceutical and food industries [10-13]. In this study, thyme oleoresin from Thymus vulgaris $L$. was used for evaluating its effect on cytochrome P450 (CYP3A4).

Cytochrome P450 is an important determinant in drug metabolism as well as in the occurrence of several drug interactions. These drug interactions can result in therapeutic failure, adverse drug reactions, and drug toxicities. Clinically, significant interactions can be prevented by identifying the drug involved as an enzyme substrate, inducer, or inhibitor and avoiding the coadministration of such drugs to get optimum response for the drugs [14].

Cytochrome P450 enzymes are primarily found in liver cells but are also located in cells throughout the body. Cytochrome P450 enzymes are located in endoplasmic reticulum and mitochondria. The enzymes found in mitochondria are generally involved in the synthesis and metabolism of internal substances, while enzymes in the endoplasmic reticulum usually metabolize external substances, primarily medications, and environmental pollutants.

CYP3A4 isozymes are responsible for the extensive first-pass metabolism and inactivation of some drugs which are administered orally $[15,16]$. It is reported that, among the six isozymes of P450 such as CYP1A2, CYP2C19, CYP2C9, CYP2D6, CYP2E1, and CYP3A4, several clinically significant drug-drug interactions have resulted from CYP3A4 isozyme $[17,18]$.

\section{MATERIALS AND METHODS}

Plant material

The thyme oleoresin from marigold flowers was obtained from Synthite Industries Private Limited, Kerala, as a gift sample.

Chemicals

CYP450 reagent, 7-Benzyloxy-4-trifluoromethylcoumarin (BFC), tris$\mathrm{HCl}$ buffer and potassium phosphate buffer. All the chemicals used were of analytical grade.

Inhibitory effect of cytochrome P450 enzyme activity (CYP3A4) About $5-100 \mu \mathrm{g} / \mathrm{ml}$ of the thyme oleoresin was used to evaluate the cytochrome P450 isoform CYP3A4 inhibitory effect. The various concentrations of thyme oleoresin, potassium phosphate buffer, CYP450 reagent, and substrate BFC were added to a 96-well plate. The mixtures were preincubated for $20 \mathrm{~min}$ at room temperature. The reaction was started by a mixture of free constituted substrate and $\mathrm{NADP}^{+}$and incubated at room temperature for 30-60 min. The reaction was stopped by tris-HCl buffer, $\mathrm{pH}$ 10.5. The fluorescent intensities of the products were measured by PerkinElmer Enspire fluorescence reader using an excitation and emission wavelength of $405 \mathrm{~nm}$ and $460 \mathrm{~nm}$, respectively. $\mathrm{IC}_{50}$ was calculated by plotting concentrations of thyme from 5 to $100 \mu \mathrm{g} / \mathrm{ml}$ against the corresponding percentage inhibition. [19].

\section{RESULTS}

In this study, all the tested concentrations of thyme showed inhibitory effect against CYP3A4 in a dose-dependent manner. At $5 \mu \mathrm{g} / \mathrm{ml}$, it showed a percentage inhibition of $1.82 \pm 0.61$, whereas $100 \mu \mathrm{g} / \mathrm{ml}$ showed $66.05 \pm 0.16$. The IC50 value for CYP3A4 inhibitory activity was found to be $39.14 \mu \mathrm{g} / \mathrm{ml}$ (Table 1 ). 


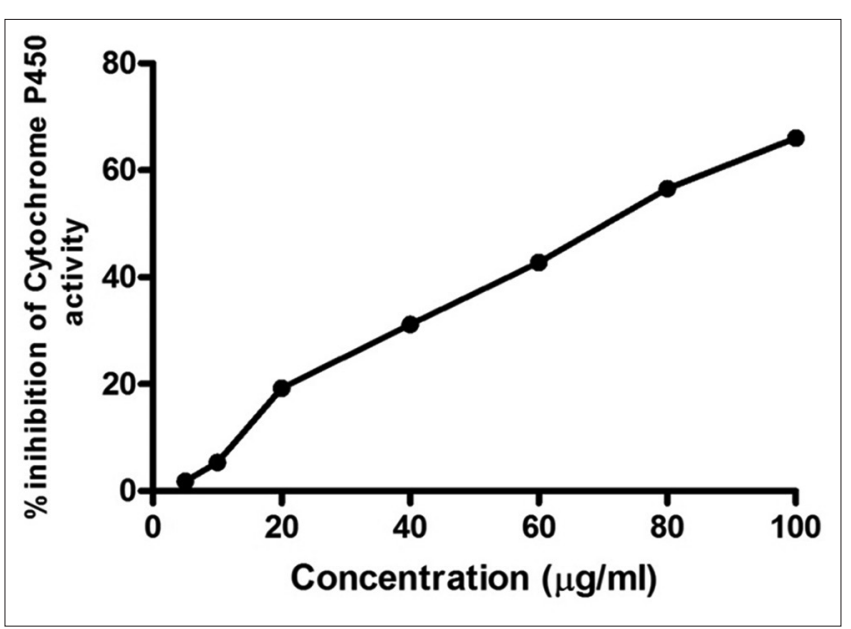

Fig. 1: Graph showing the effect of thyme oleoresin on cytochrome P450 (CYP3A4) inhibitory potential

Table 1: Effect of thyme oleoresin on cytochrome P450 (CYP3A4) inhibitory potential

\begin{tabular}{ll}
\hline Concentration $(\mu \mathrm{g} / \mathrm{ml})$ & Thyme oleoresin \\
\hline 5 & $1.82 \pm 0.61$ \\
10 & $5.38 \pm 0.44$ \\
20 & $19.20 \pm 0.36$ \\
40 & $31.16 \pm 0.20$ \\
60 & $42.76 \pm 0.32$ \\
80 & $56.55 \pm 0.77$ \\
100 & $66.05 \pm 0.16$ \\
\hline
\end{tabular}

Values are expressed as mean \pm SEM $(n=3)$

\section{DISCUSSION}

The present study shows dose-dependent inhibitory effect of thyme oleoresin on CYP3A4. (Fig 1) The $\mathrm{IC}_{50}$ value of thyme for CYP3A4 inhibitory activity was found to be $39.14 \mu \mathrm{g} / \mathrm{ml}$. Cytochrome P450 is a superfamily of hemoproteins which can be divided into families, subfamilies, and/or single enzymes. The cytochrome P450 enzymes act as a major catalyst for drug oxidation. It is the most important enzyme involved in Phase I reaction. Each enzyme of the CYP family is termed as an isoform or isoenzyme, as it is derived from different genes. CYP3A4 is an isoenzyme which is an important subset of the cytochrome P450 family which accounts for nearly $60 \%$ of the total CYP 450 in the liver and approximately $70 \%$ in the intestine. The biotransformation of many drugs is catalyzed by CYP3A and is significantly expressed extrahepatically [19].

Not only endogenous and exogenous factors but also the dietary and environmental factors can influence and affect cytochrome P450 enzyme activities [20]. Drugs can induce or inhibit cytochrome P450 and can cause clinically significant drug-drug interactions, unanticipated adverse reactions, or therapeutic failures. Interactions with many drugs such as warfarin, antidepressants, antiepileptic drugs, and statins often involve the cytochrome P450 enzymes. The possibility of adverse drug reactions and interactions can be minimized by having knowledge of the most important drugs metabolized by cytochrome P450 enzymes, as well as the most potent inhibiting and inducing drugs [21]. The high level of CYP3A4 expression in the small intestine may be the reason for CYP3A4-related interaction of food components, and moreover, more than $50 \%$ of clinical pharmaceuticals are metabolized by CYP3A4 [22].

Many plants such as Terminalia chebula and Echinacea purpurea are known for its cytochrome p450 enzyme inhibitory effect $[23,24]$. Traditional Chinese plants such as Andrographis paniculata, Arctium lappa, Acacia catechu, Bupleurum marginatum, Dysosma versipellis, and Spatholobus suberectus are also reported to have CYP3A inhibitory effect because of the presence of polyphenolics and suggests that these plants can interfere with the metabolism of concomitantly administered herbs or drugs which are metabolized by CYP3A4 [25].

Studies have even correlated the phytoconstituents responsible for cytochrome inhibitory effect. It is reported that Gynura procumbens extract with the highest content of flavonoids showed the highest inhibition of CYP3A4 and CYP1A2 enzyme activities. The ethanol extract of $G$. procumbens revealed the most potent inhibitory effect towards CYP3A4 and CYP1A2 enzyme while the methanol extract exhibited moderate inhibitory effect [26].

In the present scenario, a large population is depending on herbal medicine for a variety of health conditions such as common cold, inflammatory conditions, central nervous system diseases, heart disease, and diabetes, but their safety and efficacy data are not adequate $[27,28]$. Hence, it is always good to explore the possibility of such drug interaction for better clinical efficacy.

\section{CONCLUSION}

The findings of this study revealed that thyme oleoresin has the ability to inhibit cytochrome P450 enzyme activity, specifically CYP3A4. Hence, administration of thyme oleoresin together with herbal or modern drugs which follow the same metabolic pathway may result in herb-drug interactions.

\section{ACKNOWLEDGEMENT}

The authors thank Synthite Industries Pvt Ltd, Kerala, for providing the extract for the study and the management of Saveetha Dental College for all the support to carry out this short-term project.

\section{CONFLICTS OF INTEREST}

The authors declare that there are no conflicts of interest in publishing this article.

\section{AUTHOR'S CONTRIBUTION}

All the authors have equally contributed towards the compilation of this research article.

\section{REFERENCES}

1. Kemkar K, Sathiyanarayanan L, Sathiyanarayanan A, Mahadik K. 6-Shogaol rich ginger oleoresin loaded mixed micelles enhances in vitro cytotoxicity on MCF-7 cells and in vivo anticancer activity against DAL cells. Int J Pharm Pharm Sci 2018;10:160-8.

2. Rajalingam D, Varadharajan R, Palani S. Evaluation of hepatoprotective and antioxidant effect of Combretum albidum $g$. Don against ccl4 induced hepatotoxicity in rats. Int J Pharm Pharm Sci 2016;8:218-23.

3. Ashwini S, Anitha R. Anti-hyperglycaemic activity of Caralluma fimbriata - An in vitro approach. Pharmacogn Magn 2017;13:S499-544.

4. Ashwini S, Ezhilarasan D, Anitha R. Cytotoxic effect of Caralluma fimbriata against human colon cancer cells. Pharmacogn J 2017;9:98-101.

5. Dussault D, Vu KD, Lacroix M. In vitro evaluation of antimicrobial activities of various commercial essential oils, oleoresin and pure compounds against food pathogens and application in ham. Meat Sci 2014;96:514-20.

6. Mamdapur GM, Hadimani MB. Bibliometric analysis of research output in spices oleoresin during1994-2013: A study with reference to scifinder .Journal of Library Information Communication Technology 2016;1:38-51.

7. Shaikh J, Bhosale R, Singhal R. Microencapsulation of black pepper oleoresin. Food Chem 2006;94:105-10.

8. Nam KC, Ko KY, Min BR, Ismail H, Lee EJ, Cordray J, et al. Effects of oleoresin-tocopherol combinations on lipid oxidation, off-odor, and color of irradiated raw and cooked pork patties. Meat Sci 2007;75,61-70.

9. Upadhyay R, Mishra HN. Antioxidant activity measurement of oleoresin from rosemaryand sage. Ind Crops Prod 2011;61:453-9.

10. Zancan CK, Marques MO, Petenate AJ, Angela M, Meireles MA. Extraction of ginger (Zingiber officinale Roscoe) oleoresin with $\mathrm{CO}_{2}$ 
and co-solvents: A study of the antioxidant action of the extracts. J Supercrit Fluids 2002;24:57-76.

11. Yusop SM, O'sullivan MG, Preuß M, Weber H, Kerry JF, Kerry JP. Assessment of nanoparticle paprika oleoresin on marinating performance and sensory acceptance of poultry meat. Lwt Food Sci Technol 2012;46:349-55

12. Kurmudle N, Kagliwal LD, Bankar SB, Singhal RS. Enzyme-assisted extraction for enhanced yields of turmeric oleoresin and its constituents. Food Biosci 2013;3:36-41.

13. Rodianawati I, Hastuti P, Cahyanto M. Nutmeg's (Myristica fragrans Houtt) oleoresin: Effect of heating to chemical compositions and antifungal properties. Procedia Food Sci 2015;3:244-54.

14. Ogu CC, Maxa JL. Drug interactions due to cytochrome P450. Proc (Bayl Univ Med Cent) 2000;13:421-3.

15. Gavhane YN, Yadav AV. Loss of orally administered drugs in Gi Tract. Saudi Pharm J 2012;20:331-44

16. Capello F, Gaddi AV. Springer Clinical Handbook of Air PollutionRelated Diseases. Förlag: Springer International Publishing AG; 2018. p. 215-7.

17. Bozina N, Bradamante V, Lovric M. Genetic Polymorphism of Cyp Enzymes. Arh Hig Rada Toksikol 2009;60:217-42.

18. Zanger UM, Schwab M. Cytochrome P450 enzymes in drug metabolism: Regulation of gene expression, enzyme activities, and impact of genetic variation. Pharmacol Ther 2013;138:103-41.

19. Anannarukan N, Niwattksaiwong N, Warisnoichareon W, Winitthana T, Pramyothin $\mathrm{P}$, Chaichantipyuth $\mathrm{C}$, et al. Inhibition of human cytochrome P450 in vitro by Phyllanthus amarus and Phyllanthus emblica aqueous extracts. Thai J Pharm Sci 2012;36:135-43.
20. Cheng-Chung T. Identification and localization of five CYP2Cs in murine extrahepatic tissues and their metabolism of arachidonic acid to regio-and stereoselective products. Pharmacol Exp Ther 2001;299:39-47.

21. Purwantiningsih AH, Chan KL. Effect of standardized Eurycoma longifolia extract on Phase I rosiglitazone metabolism in the old normal male rat hepatocytes: A mechanism study. Int J Pharm Pharm Sci 2015;7:80-3.

22. Lynch T, Price A. The effect of cytochrome P450 metabolism on drug response, interactions, and adverse effects. Am Fam Physician 2007;76:391-6.

23. Fujita K. Food-drug interactions via human cytochrome P450 3A (CYP3A). Drug Metabol Drug Interact 2004;20:195-217.

24. Ponnusankar S, Pandit S, Venkatesh M, Bandyopadhyay A, Mukherjee PK. Cytochrome P450 inhibition assay for standardized extract of Terminalia chebula Retz. Phytother Res 2011;25:151-4.

25. Modarai M, Gertsch J, Suter A, Heinrich M, Kortenkamp A. Cytochrome P450 inhibitory action of Echinacea preparations differs widely and covaries with alkylamide content. J Pharm Pharmacol 2007;59:567-73.

26. Ashour ML, Youssef FS, Gad HA, Wink M. Inhibition of cytochrome P450 (CYP3A4) activity by extracts from 57 plants used in traditional chinese medicine (TCM), Pharmacogn Mag 2017;13:300-8.

27. Afandi A, Zulkiffli HM, Sadikun A, Ismail S. Antioxidant properties of Gynura procumbens extracts and their inhibitory effects on two major human recombinant cytochrome p450s using a high throughput luminescence assay. Asian J Pharm Clin Res 2014;7:36-41.

28. Zou L, Harkey MR, Henderson GL. Effects of herbal components on cDNA-expressed cytochrome p450 enzyme catalytic activity. Life Sci 2002;71:1579-89. 